\section{Teleology in Renaissance} Science

\author{
Matteo Fornasier
}

ERC Early Modern Cosmology 725883, Ca' Foscari University of Venice, Venice, Italy

\section{Abstract}

Teleology is the idea according to which every event is directed toward precise aim, even those not depending from conscious actions. The teleological interpretation of the world is particularly important in Renaissance natural philosophy because of the detachment from tradition. Nature's regularity and organization is no more attributed to God but to nature itself. Starting from the sixteenth century's Italian philosophy, nature is believed to be sensitive and intelligent in different degrees, and it implies a completely new teleological interpretation of the world.

\section{Introduction}

The etymology comes from the Greek word $\tau \varepsilon \hat{z} \lambda \circ \varsigma$ (telos) that means "purpose, aim."

It is the idea according to which every event is directed toward a precise aim, even natural events not depending from will or human conscious actions.

\section{Heritage and Rupture with the Tradition}

Aristotelism and Neoplatonism interpreted the world in a strongly teleological way. Contrary to what has been taught by Atomism, the others main philosophical schools explained the cosmos's organization and the phenomena in it with a precise project, a universal blueprint designed and organized by a superior Intellect. Medieval philosophy, guided by the cosmological ideas of the three great monotheisms - Christianity, Islam, and Hebraism - followed ancient thought in the teleological interpretation of the world. The natural philosophy of Thomas Aquinas (1226-1274), father of scholastic philosophy, attributed the intellect only to human beings and to no other thing in the material world. All other elements do not have any kind of intelligence, but the actions they perform are guided by the supreme Intellect, organizer of the cosmos, that means God.

In Thomistic natural philosophy, no natural being is gifted with intelligence, but nevertheless the actions they perform are not casual; they are intelligently directed by God toward a specific purpose. There is no intelligence or knowledge that guide the rock in its race toward the center of the earth, or the flame in its attempt to reach the skies, but they are both externally guided by the intelligence of God as well (Landucci 2005). 


\section{Innovative and Original Aspects}

The idea of universe teleologically organized is particularly important in Renaissance philosophy because of a radical change of perspective with respect to Medieval thought: from an external teleology to an internal one. Every natural event is still considered as directed toward a precise goal, and intelligence is still considered the conditio sine qua non for being able to have a precise goal, but for Renaissance philosophy of nature, intelligence must be attributed to natural things as such.

In Bernardino Telesio's (1509-1588) philosophy, every movement and every physical process in the universe are originated from the ancestral conflict between heat and cold, two incorporeal principles in perpetual opposition. The sun and earth are the cosmic locations of those two principles: the balance between earth, always motionless because of the nature of cold, and sun, always in movement because of the nature of heath, made life possible. According to Telesio, everything originates from this primordial form of life and sense that puts cold and heath one against the other, so the whole universe is sensitive in different degrees (Bondì 1997).

Telesio's most famous scholar, Tommaso Campanella (1568-1639), starting from the teachings of his master, said that thinking that God itself guides every natural thing toward its aim should be considered an insult to God's dignity. Rooted in the heath-cold conflict, the most fundamental elements have a certain form of elemental knowledge: they are able to understand what is harmful for them and what is useful for their survival. The rock is able to understand that flying in the air is harmful for its nature and staying as low as possible is good for itself: the rock falls because it attempts to reach the lowest possible place; its knowledge doesn't go further because God decided that for a simple thing like a rock is appropriate a simple form of knowledge. Just because complex beings are made of simpler beings, superior forms of knowledge are based on lower forms. Human rationality, consciousness, and intelligence are not different by nature but by degree from those of the elements, minerals, plants, or animals. According to Campanella, the greatness of God's creation lies in its independence: a creation that during his whole existence needs the intervention of its creator to reach his aims (that was how Aquinas interpreted nature) is an imperfect creation, unworthy of God's perfection (Ernst 2010).

A teleological interpretation of the universe is a characteristic of many schools of thought in history, and it opens the way to important questions. If the world is wisely organized and it's "programmed" to reach a specific purpose, how is it possible? Thanks to which power? After centuries dominated by the idea of a superior Intellect declined in many different ways that guides an almost inert nature toward its purpose, Renaissance philosophy marks a turning point in history of thought and in particular in the teleological interpretation of the world: nature is intelligent and perfect enough to understand what is the best thing to look for and to get organized to reach it (Ingegno 1988). This was a completely new kind of teleological understanding and a new idea of nature's dignity.

\section{Cross-References}

\author{
Bernardino Telesio \\ Causes \\ Natural Philosophy \\ Thomas Aquinas \\ Tommaso Campanella
}

\section{References}

Bondì, Roberto. 1997. Introduzione a Telesio. Bari: Laterza.

Ernst, Germana. 2010. Tommaso Campanella. Il libro e il corpo della natura. Laterza: Bari.

Ingegno, Alfonso. 1988. The New Philosophy of Nature. In The Cambridge History of Renaissance Philosohy, 236-263, ed. by Schmitt C. B., Skinner Q. Cambridge: Cambridge University Press.

Landucci, Sergio. 2005. I filosofi e Dio. Bari: Laterza. 